\title{
PENGARUH MANAJEMEN TALENTA DAN MANAJEMEN PENGETAHUAN TERHADAP KINERJA KARYAWAN DI TRANSFORMER CENTER KABUPATEN BATU
}

\author{
Kardo \\ (Program Studi Manajemen, Fakultas Ekonomika dan Bisnis Ekonomi Universitas Kanjuruhan, Malang) \\ e-mail: Kardo.hineni@gmail.com \\ Sri Wilujeng \\ Dianawati Suryaningtyas \\ (Program Studi Manajemen, Fakultas Ekonomika dan Bisnis, Universitas Kanjuruhan, Malang)
}

\begin{abstract}
Abstrak: Penelitian ini bertujuan untuk: (1)Menguji pengaruh Manajemen Talenta dan Manajemen Pengetahuan Terhadap Kinerja. (2)Menguji pengaruh manajemen Talenta terhadap Kinerja Karyawan di Transfoermer Center. (3)Menguji pengaruh Manajemen Pengetahuan Terhadap Kinerja di Transformer Center. Penelitian ini menggunakan teknik analisis yang menggunakan pendekatan kuantitatif deskriptif, yaitu penelitian dengan angka yang kemudian di deskripsikan. Penelitian ini juga menggunakan metode analisis berupa regresi linier berganda. Populasi dan sampel yang peneliti gunakan yakni di Transformer Center Kota Batu dengan sampel sebesar 75 orang karyawan tetap, teknik yang digunakan yakni menggunakan tenik sensus (sampel jenuh). Hasil penelitian ini menunjukan bahwa variabel Manajemen Talenta dan Manajemen Pengatahuan berpengaruh positif dan signifikan terhadap kinerja yang ada di Transformer Center Kota Batu. Variabel Manajemen Talenta berpengaruh positif dan signifikan terhadap Kinerja Karyawan di Transformer Center Kota Batu, variabel Manajemen Pengetahuan berpengearuh positif dan signifikan searah terhadap Kinerja Karyawan di Transformer Center Kota Batu. Artinya semakin tinggi Manajemen Talenta dan Manajemen Pengetahuan dimiliki Transformer Center Kota Batu maka semakin baik pula kedua variabel mempengaruhi Kinerja yang ada di perusahaan. Bagi penelitian selanjutny: diharapkan melakukan penelitian menggunakan variabel yang berbeda, misalnya dispilin kerja, pelatihan dan pengembangan karyawan, yang termasuk mempengaruhi kinerja yang belum di teliti dalam penelitian.
\end{abstract}

Kata kunci: Manajemen Talenta, Manajemen Pengetahuan, Kinerja Karyawan

\section{PENDAHULUAN}

Sebuah Perusahaan Untuk dapat bertumbuh dan berkembang di tengah perubahan lingkungan eksternal yang lebih pesat, harus memfokuskan diri kepada perubahan faktor internalnya yaitu untuk mencari, menarik bahkan mempertahankan karyawan yang memiliki keunggulan talenta bagi perusahaan dan dalam divisi yang dijalankannya. Hanya orang-orang terbaik dan mereka yang memiliki potensi yang lebih dan jumlah yang cukup, pada posisi yang tepat dan dengan pendayagunaan yang optimal yang dapat mendorong perusahaan untuk berkembang.

Berhasilnya suatu orangisasi atau perusahan tidak terlepas dari kinerja karyawan, salah satu upaya yang dilakukan oleh perusahaan dalam mempertahankan kinerja karyawan ialah dengan menerapkan adanya Manajemen Talenta dan Manajemen Pengatahuan. Manajemen Talenta dalam perusahaan sangat bermanfaat untuk memberikan kontribusi yang baik pada kinerja perusahaan. Salah satu cara yang dilakukan oleh perusahaan untuk meningkatkan kinerja di lihat dari manajemen Talenta yaitu dengan adanya pemetaan talenta yang baik sehingga dalam penempatan posisi pekerjaan sesuai dengan kemampuan dan Talenta yang dimilki oleh karyawan itu sendiri sehingga kinerja mengalami peningkatan

Manajemen talenta adalah serangkaian proses yang dilakukan perusahaan untuk mengidentifikasi, mengembangkan, mempertahankan dan menempatkan orang yang tepat di tempat yang tepat. Manajemen talenta dalam pandangan manajemen strategi yaitu untuk melakukan pengelolaan jalur Talenta dalam satu 
Pengaruh Manajemen Talenta Dan Manajemen Pengetahuan Terhadap Kinerja Karyawan Di Transformer Center Kabupaten Batu

lingkup perusahaan dimana tujuannya untuk memberikan kepastian tersediannya dalam penelitian Hanum Aula

Rahmawati (2019) menjelaskan bahwa Manajemen talenta berpengaruh signifikan terhadap kinerja karyawan serta berkontribusi untuk memberikan pengaruh yang signifikan kepada kinerja yang ada pada setiap divisi.

Manajemen Pengatahuan merupakan sistem yang dibuat untuk menciptakan, mendokumentasikan, menggolongkan, dan menyebarkan Pengetahuan dalam sebuah organisasi (Widayana, 2015). Dalam penelitian Indra Taruna Anggapraja (2016), menyatakan bahwa Hasil pengujian secara parsial besarnya pengaruh penerapan Manajemen Pengetahuan terhadap kinerja karyawan adalah berpengaruh signifikan tarhadap kinerja.

\section{TINJAUAN PUSTAKA}

Kinerja merupakan hasil dari pekerjaan yang memiliki hubungan kuat dengan tujuan strategi organisasi, kepuasan konsumen dan memberikan kontribusi kepada ekonomi Wibowo (2012). Kinerja didalam suatu perusahaan merupakan kewajiban yang dilakuakan oleh segenap Sumber Daya Manusia yang ada dalam organisasi, baik didalam nya unsur pemimpin maupun pekerjanya. Dimana karyawan berkualitas dan memiliki pengetahun yang tinggi, akan sangat mempengaruhi peningkatan kinerja dari pegawai itu sendiri, serta meningkatnya perstasi perusahaan diamana mereka bekerj, sehingga tujuan dari perusahaan yang telah ditentukan sebelumnya dapat tercapai sesuai dengan yang di harapkan. Peningkatan kinerja pegawai akan membawa kemajuan yang signifikan bagi perusahaan untuk dapat tetap bertahan dalam lingkup persaingan bisnis baik produksi maupun jasa yang tidak stabil

"Manajemen talenta adalah faktor pembeda kinerja organisasi, talenta dapat juga diartikan karyawan yang diidentifikasi memiliki potensi menjadi pemimpin masa depan perusahaan" Pella dan Inayati (2011). Manajemen Pengetahuan merupakan suatu displin ilmu yang sangat penting untuk mentransfer ilmu pengethuan, keterampilan,dan perilaku kerja efektif. Penerapan Manajemen Pengetahuan di ACC telah mampu membuat perusahaan secara berkala mencetak tenaga terampil di industry non Bank dengan berbagai sharing case study di industry. Dengan referensi studi ilmiah yang di tulis oleh Prof. Andreas Budihardjo, meyakinkan bahwa KM akan mempermudah pemahaman industrial untuk menerapkan pengetahuan secara konsisten dan akan menjadi legacy masing-masing perusahaan kedepan ( Jodjana Jody, 2018)

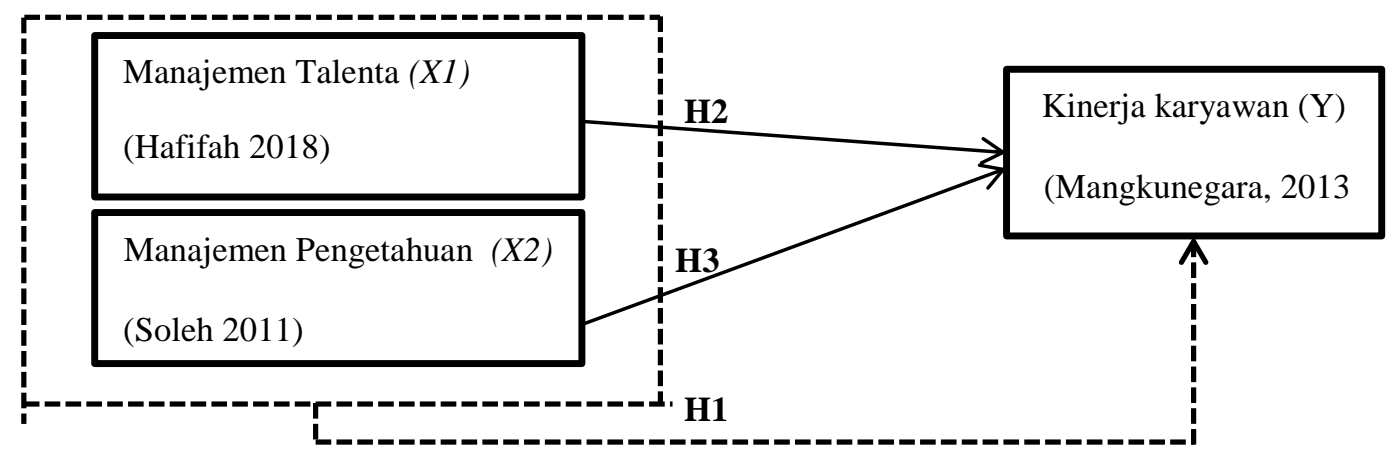

Gambar 2.1

\section{Kerangka Konsep Penelitiaan}

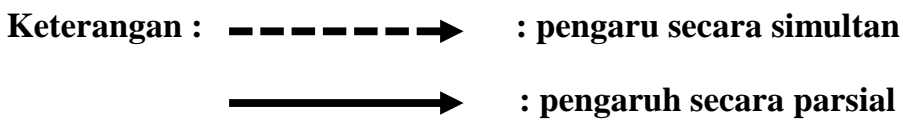

H1 : Manajemen Talenta Dan Manajemen Pengetahuan berpengaruh terhadap kinerja karyawan pada karyawan Transformer Center Kota Batu 
Pengaruh Manajemen Talenta Dan Manajemen Pengetahuan Terhadap Kinerja Karyawan Di Transformer Center Kabupaten Batu

H2 : Manajemen Talenta berpengaruh terhadap kinerja pada karyawan Transformer Center Kota Batu

H3 : Manajemen Pengetahuan berpengaruh terhadap kinerja karyawan pada karyawan Transformer Center Kota Batu

\section{METODE PENELITIAN}

Penelitian ini juga menggunakan metode analisis berupa regresi linier berganda. Populasi dan sampel yang peneliti gunakan yakni di Transformer Center kota batu dengan sampel sebesar 75 orang karyawan tetap, teknik yang digunakan yakni menggunakan tenik sensus (sampel sensus, sampel jenuh ). Hasil penelitian ini menunjukan variabel Manajemen Talenta dan Manajemen Pengatahuan berpengaruh positif dan signiikan terhadap kinerja yang ada di Transformer Center Kota Batu

\section{HASIL DAN PEMBAHASAN}

Dalam penelitian ini karaakteristk reponden yang dapat di golongkan berdasarkan jenis kelamin, usia, dan berdasarkan tingkat pendidikan. Berdasasrkan karakteristik tersebut maka dapat di simpulkan bahwa jenis kelamin dominan perempuan sebanyak 42 orang atau 56\% dan laki-laki sebanyak 33 orang atau 44\%. Kemudian berdasarka rata-rata usia pada karyawan Transformer Center dapat kita lihat usia $<20$ tahun sebanyak 5 orang atau 7\%, kemudian 21-30 sebanyak 52 orang atau 69\%, usia 31-40 sebanyak 6 orang atau 8\%, usia 42-50 sebanyak 10 orang atau $13 \%$ kemudian usia diatas 50 tahun sebanyak 2 orang atau $3 \%$. Kemudian di lihat dari tingkat pendidikan yang ada di Transformer Center dari tingkat SMP sebanyak 2 orang atau 3\%, tingkat pendidikan SMA 60 orang atau 80\%, tingkat pendidikan S1 sebnayak 5 orang atau 7\%, tingkat pendidikan S2 sebnayak 7 orang atau 9\%, dan kemudian tingkat pendidikan S3 sebanyak 1 orang atau 1\%. Dari hasil uji validitas dari semua item dan pernyataan dikatakan Valid sehingga semua item dapt digunakan untuk dianalisis lebih lanjut, hal ini dapat di tunjukan dengan nilai korelasi $r$ hitung lebih besar dari $\mathrm{r}$ tabel sebesar 0,227. Kemudian dilihat dari hasil uji reabilitas penelitian ini dikatakan reliable karena memiliki nilai alfa cronbach lebih dari 0,6.

Hasil analisis deskriptip kinerja karyawan dapat disimpulkan bahwa item pertanyaan yang di ajukan memiliki nilai yang lebih unggul dapat kita lihat pada perilaku kerjasama sedangkan item terrendah adalah pelaksanaan sesuai tujuan. Dari hasil tersebut dapat di artikan bahawa kinerja karyawan yang ada di Transformer Center selalau mengutamakan kerjasama antara team kerja, pencapaiyan kerja yang baik dihasilkan karena adanya kerja sama antara team yang baik pula. Kemudian dari hasil analisis deskriptip Manajemen Talenta dapat di simpulkan dari frekuensi jawaban responden yang ungul yaitu mampu mengikuti pengembangan talenta, artinya Transformer Center akan selalu meningkatakan talent dalam perusahaan ketika karyawannya mampu mengikuti adanya pengembangan talenta yang ada di perusahaan. Kemudian hasil analisis deskriptip Manajemen Pengetahuan dapat disimpulkan bahwa pernyataan yang unggul ialah peningkatan pengetahuan, artinya di Transformer Center jika ingin meningkatkan pengetahuan maka dari pihak perusahaan harus mampu melakukan penngkatan pengetahuan yang ada setiap karyawan.

\section{Uji Asumsi Klasik}

Berdasarkan hasil normalitas dapat kita ketahui bahwa data yang di peroleh berada di sekitar garis diagonal atau mengikuti garis diagonal, hal ini menunjukan bahwa data yang tersebut dapat dikatakan normal dan model data tersebut layak digunakan. Hasil uji heteroskedastisitas dapat di ketahuai bahwa titik-titik menyebar secara acak artinya, pada penelitian ini tidak terjadi heteroskedastisitas.

\section{Regresi Linier Berganda}

Tabel 4.13

Output Regresi Linier Berganda

\begin{tabular}{|c|c|c|c|c|c|}
\hline \multirow[t]{2}{*}{ Variabel Independen } & \multicolumn{2}{|c|}{ Unstandardized coeffcients } & \multirow[t]{2}{*}{ Beta } & \multirow[t]{2}{*}{ t-hitung } & \multirow[t]{2}{*}{ Sign.T } \\
\hline & B & Std.Error & & & \\
\hline (Constand) & 7.701 & 5.374 & & 1.433 & 0,156 \\
\hline Manajemen Talenta (X1) & 0,548 & 0,155 & 0,490 & 3.530 & 0,001 \\
\hline
\end{tabular}


Pengaruh Manajemen Talenta Dan Manajemen Pengetahuan Terhadap Kinerja Karyawan Di Transformer Center Kabupaten Batu

\begin{tabular}{|l|l|l|l|l|l|}
\hline Manajemen pengetahuan (X2) & 0,392 & 0,188 & 0,290 & 2.089 & 0,040 \\
\hline Adjusted R square & 0,545 & \multicolumn{4}{|l}{} \\
\cline { 1 - 3 } F-hitung & 45.381 & & & \\
Sign-F & 0,000 & & & & \\
\hline Variabel Dependen = Kinerja Karyawan
\end{tabular}

Sumber : Output SPSS, data diolah 2020

Dari tabel di atas maka persamaan regresi sebagai berikut :

$\mathrm{Y}=7,701+0,548 \mathrm{X} 1+0,392 \mathrm{X} 2+\mathrm{e}$

Dari persamaan regresi tersebut, diketahui bahwa :

Nilai konstanta sebesar 7,701 memiliki arti variabel

Variabel Manajemen Talenta (X1) memiliki nilai koefisien positif sebesar 0,548. Hal ini menyatakan bahwa setiap satu variabel Manajemen Talenta (X1) akan memberikan pengaruh sebesar 0,548 terhadap Kinerja Karyawan (Y) apabila variabel lainya tetap. Data tersebut menunjukan bahwa Manajemen Talenta (X1) berpengaruh positif (searah) terhadap Kinerja Karyawan. Artinya semakin baik Manajemen Talenta (X1) maka semakain baik pula Kinerja Karyawan yang ada di Transformer Center.

Variabel manajemen pengetahuan (X2) memiliki nilai koefisien regresi positif sebesar 0,392. Hal ini meyatakan bahwa setiap satu kesatuan variabel Manajemen Pengetahuan (X2) akan memberi pengaruh sebesar 0,392 terhadap Kinerja Karyawan (Y) apa bila variabel lain tetap. Data tersebut menunjukan bahwa Manajemen Pengetahuan (X2) berpengaruh positif (searah) terhadap Kinerja Krayawan (Y), artinya semakin baik Manajemen Pengetahuan (X2) maka semakin tinggi pula Kinerja Karyawan (Y).

\section{Uji Hipotesis}

\section{Uji t}

Uji t dilakukan untuk memahami pengaruh secara parsial pada masing-masing variabel bebas terhadap variabel terikat. Untuk menentukan suatu hipotesis dapat diterima atau ditolak dapat melalui perbandingan antara $t$ hitung dengan $t$ tabel, atau dapat juga melihat dari nilai signifikansi yang ada dengan penetatapan batas kesalahan sebesar 0,05. Berikut adalah ketentuan hipotesis diterima atau ditolak. Berdasarkan hasil analisis yang telah peneliti teliti maka dapat kita lihat penjelasan di bawah ini

Pengujian H1 : Nilai thitung pada variabel Manajemen Talenta sebesar 3,530 dengan nilai Beta 0,490 dan nilai siginifikansi sebesar 0,001. Dapat dilihat bahwa nilai sig $<0,05$ maka dapat disimpulkan bahwa H1 diterima yaitu dengan kata lain ada pengaruh positif antara Manajemen Talenta (X1) dengan kinerja karyawan (Y).

Pengujian H2 : Nilai t hitung pada variabel Manajemen Pengetahuan (X2) sebesar 3,530 dengan nilai Beta 0,290 dan nilai siginifikansi sebesar 0,040. Dapat dilihat bahwa nilai sig < 0,05 maka dapat disimpulkan bahwa $\mathrm{H} 2$ diterima tetapi memiliki pengaruh yang positif yaitu antara Manajemen Pengetahuan (X2) dengan kinerja karyawan (Y).

\section{Uji F}

Uji F dilakukan untuk mengetahui pengaruh dari kesemua variabel bebas terhadap variabel terikat dengan cara simultan. Dalam menentukan suatu hipotesis diterima atau ditolak adalah dengan membandingkan $\mathrm{F}$ hitung dengan $\mathrm{F}$ tabel, atau dapat juga melihat dari nilai signifikansi yang ada dengan penetatapan batas kesalahan sebesar 0,05. Berikut adalah ketentuan hipotesis diterima atau ditolak.

Berdasarkan hasil analisis di atas, uji $\mathrm{F}$ yaitu pengujian secara serentak (simultan) menunjukkan hasil $\mathrm{F}_{\text {hitung }}$ sebesar 45,381 dengan nilai signifikansi (0.000) yang jauh lebih kecil dari alpha 0.05. Hal ini menunjukkan adanya pengaruh yang signifikan secara simultan dari Manajemen Talenta (X1) dan Manajemen Pengatahuan (X2) secara simultan terhadap kierja karyawan di Transformer Center.

\section{Koefisien Determinasi}


Pengaruh Manajemen Talenta Dan Manajemen Pengetahuan Terhadap Kinerja Karyawan Di Transformer Center Kabupaten Batu

Koefisien Determinasi pada intinya mengukur seberapa jauh kemampuan model dalam menerangkan variasi Variabel dependen. Besarnya koefisien determinasi adalah 0 samapai dengan 1. Nilai R2 yang kecil berarti kemampuan variabel-variabel Independen dalam menjelaskan variasi variabel dependen sangat terbatas. Nilai yang mendekati 1 berarti variabel-variabel independen memeberikan hampir semua informasi yang dibutuhkan untuk memprediksi variasi-variasi variabel depende.

Hasil analisis diatas menjelaskan bahwa nilai pada koefisien determinasi (R Square) sebesar 0,545 atau jika diubah dalam bentuk presentase menjadi sebesar 54,5\%. Hasil ini dapat menjelaskan bahwa kecerdasan intelektual, kecerdasan emosional, dan kecerdasan spiritual memberikan pengaruh terhadap kinerja karyawan

sebesar $54,5 \%$. Sedangkan untuk sisanya yang senilai $45,5 \%$ dipengaruhi oleh variabel lainnya yang tidak diteliti saat ini

\section{Pembahasan}

Pengaruh Manajemen Talenta dan Manajemen Pengetahuan Terhadap Kinerja Karyawan

Berdasarkan hasil analisis yang sudah dijelaskan untuk mengetahui pengaruh Manajemen Talenta dan Manajemen Pengetahuan setelah diuji bersama-sama memiliki pengaruh yang signifikan terhadap kinerja Karyawan. Berdasarkan dari penelitian yang dilakukan bahwa variabel kinerja karyawan di faktori oleh kualitas, kuantitas, tanggung jawab, kerjasama dan inisiatif dalam bekerja. Adapun faktor yang dominan mempengeruh sangat besar terhadap kinerja adalah tanggung jawab karyawan terhadap pekarjaan yang dikerjakan, tanggung jawab disini meliputi bagaimana karyawan mampu menunjukan adanya kerjasama yang baik serta dapat betanggung jawab terhadap hasil kerja yang di lakukan.

Variabel Manajemen Talenta mempengaruhi Kinerja Karyawan di Transformer Center didasari oleh perencanaan talenta, identifikasi talenta, pengembangan talenta, dan jaringan talenta. Manajemen Talenta lebih besar di pengaruhi oleh adanya faktor pengembagan talenta yang dimana faktor tersebut di pengaruhi oleh karyawan yang mampu mengaplikasikan talenta serta mampu mengikuti pengembangan talenta di perusahaan. Adapaun variabel Manajemen Pengetahuan mempengaruhi Kinerja Karyawan yang didukung dengan adanya identifikasi, refleksi, berbagi pengetahuan dan pengguna pengetahuan. Pengguna pengetahuan menjadi komponen terbesar yang mempengaruhi adanya penerapan manajemen pengetahuan yang ada di perusahaan dan dipengaruhi oleh adanya perencanaan informasi, perolehan informasi dan pencipta informasi..

Melalui hasil tersebut dapat dijelaskan bahwa ketika Manajemen Talenta dan Manajemen Pengetahuan di Transformer Center digabungkan menjadi satu akan memiliki pengaruh yang signifikan dan memberikan efek yang positif terhadap kinerja Pada perusahaan.

Pengaruh Manajemen Talenta Terhadap Kinerja Karyawan Transformer Center

Berdasarkan pada hasil analisis pada bab sebelumnya telah diketahui bahwa untuk pengaruh hubungan antara Manajemen Talenta terhadap kinerja karyawan memiliki pengaruh yang signifikan dan juga hubungan yang positif. Dari hasil tersebut dapat menjelaskan bahwa Manajemen Talenta dan kinerja di Transformer Center memiliki pergerakan yang searah, dan dapat dilihat dari faktor yang mempengaruhi adanya Manajemen Talenta di antaranya perencanaan talenta, pengembangan talenta, manajemen talenta dan jaringan talenta. Hasil yang dominan pada variabel ini ialah adanya pengembangan talenta yang di terapkan di perusahaan sehingga karyawan mampu mengembangkan talenta dan mampu mengaplikasikan talenta yang di miliki oleh setiap individu sehingga dapat mempengaruhi kinerja dengan baik.

Penjelasan diatas memiliki arti ketika perusahaan ingin peningkatan dari kinerja karayawannya hal yang perlu dilakukan adalah dengan menambah nilai pada ke karyawan tersebut. Semakin tinggi Manajemen Talenta di Transformer Center, maka akan berdampak pada kinerja yang semakin baik pula.

\section{Pengaruh Manajemen Pengetahuan Terhadap Kinerja Karyawan Transformer Center}

Berdasarkan pada hasil analisis pada bab sebelumnya telah diketahui bahwa untuk pengaruh hubungan antara Manajemen Pengetahuan terhadap kinerja karyawan memiliki pengaruh yang signifikan. Hasil signifikan yang ada, dipengaruhi oleh adanya faktor identifikasi pengetahuan, refelksi pengetahuan, berbagi pengetahuan dan pengguna pengetahuan, dari bebrapa faktor diatas yang sangat dominan mempengaruhi kinerja yang ada di Transformer Center ialah penggunaan pengetahuan yang baik sehingga dalam penggunaan tersebut terlihat 
Pengaruh Manajemen Talenta Dan Manajemen Pengetahuan Terhadap Kinerja Karyawan Di Transformer Center Kabupaten Batu

adanya perencanaan informasi, pengelolaan informasi serta adanya penciptaan informasi yang ada di perusahaan terutama yang ada di setiap divisi.

Dari hasil tersebut dapat menjelaskan bahwa manajemen pengetahuan dan kinerja di Transformer Center memiliki pergerakan yang searah, artinya ketika perusahaan ingin peningkatan dari kinerja karayawannya hal yang perlu dilakukan adalah dengan menambah nilai pada ke karyawan tersebut. Semakin tinggi manajemen pengetahuan di Transformer Center, maka akan berdampak pada kinerjanya yang semakin baik pula. Karena karyawan tersebut akan lebih mudah dalam melakuakan aktivitas pekerjaan yang sesuia dengan bidang yang mereka jalankan dan yang mengaplikasikannya pada cara menyelesaikan pekerjaan yang lebih baik.

\section{KESIMPULAN}

Berdasarkan hasil penelitian yang telah dibahas tentang pengaruh manajemen talenta dan manajemen pengetahuan terhadap kinerja karyawan yang ada di Transformer Center Kota Batu, dapat disimpulkan bahwa manajemen talenta dan manajemen pengetahuan berpengeruh signifikan terhadap kinerja karyawan yang ada di Transformer Center Kota baru, manajemen talenta berpengaruh terhadap kinerja karyawan yang ada di Transformer Center Kota Batu, manajemen Pengetahuan berpengeruh signifikan terhadap kinerja karyawan yang ada di Transformer Center Kota Batu.

\section{SARAN}

Berdasarkan hasil dari penelitian, peneliti berharap hasil yang di peroleh bisa dijadikan landasan untuk penelitian selanjutnya. Peneliti juga berharap kepada penelitian selanjutnya untuk dapat menilai setiap variabelvariabel yang digunakan dan mengharapkan penelitian selanjutnya melakukan penelitian menggunakan varibel yang berbeda, misalnya disiplin kerja, pelatihan dan pengembangan karyawan.

\section{DAFTAR PUSTAKA.}

Amstrong, Michael. 2014. A Handbook of Human Resources Management Practice. 13th edtion. Philadelphia: Kogan Page.

Angga, Taruna I. dalam penelitian berjudul pengaruh Manajemen Talenta dan Pengembangan Sumber Daya Manusia Terhadap Kinerja Karyawan PT Telkom Tbk. (Studi Explanatory Survey Pada Karyawan Unit Human Capital Management PT Telkom Tbk.). Jurnal Aplikasi Manajemen (JAM) Vol 14 No 1, 2016 Terindeks dalam Google Scholar. Universitas Widyatama

Anggapraja, Taruna, Indra 2016, Pengaruh Penerapan Knowledge Management

Arikunto. 2005. Metode Penelitian Kualitatif. Jakarta: Sagung Seto. Bayu media publishing. Jawa Timur

Budihardjo, Andreas 2018 Knowledge Management. Presetya Mulya Publishing, Universitas Prasetya Mulya. Cilandak barat Jakarta

Bungin, Burhan. 2003. Analisa Data Penelitian Kualitatif: Pemahaman Filosofis dan Metodologis ke Arah Penguasaan Model Aplikasi. Jakarta : Raja Grafindo Persada

Kosasih, Natalia 2017, Pengaruh Knowledge Management Terhadap Kinerja Karyawan: Studi Kasus Departemen Front Office Surabaya Plaza Hotel. Jurnal Manajemen Perhotelan, VOL.3, NO.2, September 2007: 80-8

Mangkunegara 2013 Manajemen Sumber Daya Manusia Perusahaan Bandung: PT. Remaja Rosdakarya.

Pella,Ahmad.d 2018 Talent Management. PT.Gramedia Pustaka Utama, kompas gramedia bulding.Jakarta 10270

Rachmadinata Satria Niko, Ayuningtias Gita H. (2017), Pengaruh Manajemen Talenta Terhadap Kinerja Karyawan Lintasarta Kota Jakarta, Jurnal Manajemen Indonesia Vol.17 No.3Desember 2017

Saputri, Handika ,S 14220088 (2018) Skripsi, Pengaruh Knowledge Management, Skill dan Kompetensi Kinerja Karyawan di The Bagong Adventure Museum tubuh Universitas Merdeka Malang

Soleh, Alvian . 2011 Smart Knowledge Worker. Jakarta: Knowledge Management plus

Wibowo. 2012. Manajemen Kinerja: Jakarta: Garafindo persada

Zargar Ehsan, Rezaee Masoomeh (2013), The Study of Knowledge Management Effect on Performance Rate of Employees, Eureopean Online Journal Of Nature and National Sceinces 2013, vol 02, no 03 special issuce om accounting and management. ISSN1805-3602 
Pengaruh Manajemen Talenta Dan Manajemen Pengetahuan Terhadap Kinerja Karyawan Di Transformer Center Kabupaten Batu

Zuhal.2010. knowledge dan Inovation. Jakarta: PT.Gramedia pustaka Umum 